НАУКОВИЙ ВІСНИК

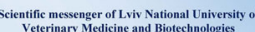

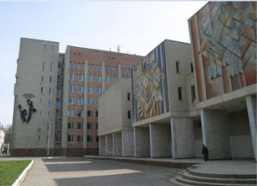

СЕРЯя: ВЕТЕРИНАРНН НАУКИ

Том 23 № 101

2021
Науковий вісник Дьвівського національного університету ветеринарної медицини та біотехнологій імені С.3. Гжицького. Серія: Ветеринарні науки

\author{
Scientific Messenger of Lviv National University \\ of Veterinary Medicine and Biotechnologies. \\ Series: Veterinary sciences
}

UDC 619:636.1.09

\title{
The efficiency of the drug based on butaphosphane, B vitamins and L-carnitine in the treatment of horses
}

O. M. Pyatnychko ${ }^{1}$, M. I. Zhyla ${ }^{1}$, N. V. Shkodyak ${ }^{1}$, O. O. Saliy ${ }^{2}$, M. V. Derkach ${ }^{2}$, L. V. Kalynovska ${ }^{1}$

${ }^{I}$ State Scientific-Research Control Institute of Veterinary Medicinal Products and Feed Additives, Lviv, Ukraine

"Biotestlab" Ltd, Kyiv, Ukraine

Article info

Received 28.12.2020

Received in revised form 28.01 .2021

Accepted 29.01.2021

State Scientific-Research Control Institute of Veterinary Medicinal

Products and Feed Additives,

Donetska Str., 11, Lviv, 79019,

Ukraine.

Tel: + 38-067-706-96-11

E-mail: zhyla-m@ukr.net

“BIOTESTLAB” Ltd,

Akademika Lebedeva Str., 1 ,

Kyiv, 02000, Ukraine.

Tel.: +38-097-256-46-20

E-mail:e_saliy@biotestlab.net
Pyatnychko O. M., Zhyla M. I., Shkodyak N. V., Saliy O. O., Derkach M. V., \& Kalynovska L. V. (2021). The efficiency of the drug based on butaphosphane, $B$ vitamins and L-carnitine in the treatment of horses. Scientific Messenger of Lviv National University of Veterinary Medicine and Biotechnologies. Series: Veterinary sciences, 23(101), 31-37. doi: 10.32718/nvlvet10106

An important feature of living organisms, acquired in the process of evolution, is the ability to adapt to various external influences and changes in the environment, to maintain homeostasis and regulatory processes in organs, systems and the body as a whole. However, with modern breeding technologies, the physiological capabilities of the animal's body are often unable to change as quickly as required by the conditions of industrial maintenance, which leads to stress. Vitamin preparations and biologically active feed additives are widely used by veterinary medicine specialists to increase resistance to stressful situations, disease prevention, increase resistance, safety and productivity of farm animals. Preparation L-tsyn, solution for injection (manufactured by BIOTESTLAB LLC), is a drug, the action of which is due to the prescription combination of active substances, namely: butaphosphane, B vitamins (vitamin $B_{12}$, vitamin $B_{3}$ ) and $L$-carnitine. The aim of the study was to investigate the effectiveness of the drug L-tsyn on horses under the influence of stressors of various natures. Two experiments on working horses with constant, excessive physical activity with chronic exercises and with complex therapy of intoxication with signs of acute renal failure in horse were conducted. Clinical trials of the drug were performed on working horses aged 5-15 years, of different sexes. The drug was administered in a dose of 20-25 ml per animal, 1 time per day for 5 consecutive days. The clinical condition of the experimental animals was observed for 21 days from the start of the drug. The morpho-functional state of the animal's body before and after the drug was established according to the indicators of the clinical condition, morphological and biochemical parameters of the blood, which were determined according to generally accepted methods. In working horses under excessive load the drug L-tsyn activated the processes of hematopoiesis, improved the physiological state of the body and contributed to the increase the general tone of the body. The drug as part of complex therapy in the treatment of intoxication, showed hepato- and nephroprotective properties, reduced the manifestations of intoxication, helped to restoration of the animal's normal physiological state. According to the results of clinical, hematological and biochemical studies, it can be concluded that the drug L-tsyn has a stimulating effect on metabolic processes in the animals' body, shows tonic properties, increases the body's resistance to toxins and adverse environmental factors and can be used as monotherapy and for the complex treatment of diseases of various etiologies in horses.

Key words: horses, stress factors, L-tsyn veterinary drug, clinical, hematological, biochemical studies.

\section{Ефективність застосування препарату на основі бутафосфану, вітамінів групи B та L-карнітину при лікуванні коней}

\author{
О. М. П’ятничко ${ }^{1}$, М. І. Жила ${ }^{1}$, Н. В. Шкодяк ${ }^{1}$, О. О. Салій², М. В. Деркач², Л. В. Калиновська ${ }^{1}$ \\ ${ }^{1}$ Державний науково-дослідний контрольний інститут ветеринарних препаратів та кормових добавок, \\ м. Львів, Україна \\ ${ }^{2}$ ТОВ “БІОТЕСТЛАБ”, м. Київ, Україна
}


Важливою особливістю живих організмів, набутою в проиесі еволюиї, $є$ здатність адаптуватися до різних зовнішніх впливів $i$ змін навколишнього середовища, підтримувати гомеостаз і регулячійні процеси в органах, системах та організмі в иілому. Проте за сучасних технологій вирочування фізіологічні можливості організму тварин часто не в змозі змінюватися так швидко, як того вимагають умови промислового утримання, щуо призводить до виникнення стресового стану. Для підвищення стійкості до стресових ситуацій, профілактики захворювань, підвищення резистентності, збереженості та продуктивності сільськогосподарських тварин спеціалістами ветеринарної медицини иироко використовуються вітамінні препарати та біологічно активні кормові добавки. Препарат L-Цин, розчин для ін 'єкцій (виробництва ТОВ “БІОТЕСТЛАБ”), є лікарським засобом вітчизняного виробництва, дія якого зумовлена рецептурною комбінацією активнодіючих речовин, а саме: бутафосфаном, вітамінами групи В (вітаміном $B_{12}$, вітаміном $\left.B_{3}\right)$ та L-карнітином. Метою роботи було дослідити ефективність застосування препарату L-uин на конях за впливу стрес-факторів різної етіології. Проведено два досліди: на робочих конях при постійних, надмірних фізичних навантаженнях та при комплексній терапії інтоксикації з ознаками гострої ниркової недостатності у коня. Клінічні випробування препарату проводили на робочих конях віком 5-15 років, різної статі. Препарат вводили в дозі 20-25 мл на тварину 1 раз на добу, впродовж 5 діб поспіль. За клінічним станом дослідних тварин спостерігали упродовж 21 доби від початку застосування препарату. Морфофункиіональний стан організму тварин до та після застосування препарату встановлювали за клінічним станом, морфологічними та біохімічними показниками крові, які визначали згідно зі загальноприйнятими методиками. При надмірному навантаженні у робочих коней препарат L-циин активував процеси кровотворення, поліпшував показники фізіологічного стану тварин та сприяв підвищенню загального тонусу організму. У складі комплексної терапії при інтоксикації препарат виявляв гепато- та нефропротекторну властивості, зменшував прояви інтоксикації, сприяв відновленню фізіологічного стану хворої тварини. За результатами клінічних, гематологічних та біохімічних досліджень можна зробити висновок, щзо ветеринарний препарат L-цฺин стимулююче впливає на метаболічні процеси в організмі, проявляє тонізуючі властивості, підвищує резистентність організму до несприятливих факторів зовнішнього середовища і може бути застосований як за монотерапії, так $і$ для комплексного лікування захворювань різної етіології у коней.

Ключові слова: коні, стрес-фактори, ветеринарний препарат L-цин, клінічні, гематологічні, біохімічні дослідження.

\section{Ветуп}

Важливою особливістю всіх живих організмів, набутою в процесі еволюції, є здатність адаптуватися до різних зовнішніх впливів і змін навколишнього середовища, підтримувати гомеостаз і регуляційні процеси в органах, системах та організмі в цілому. Сучасні методи інтенсивного вирощування тварин в умовах господарств різного типу з використанням високопродуктивних порід і впровадження промислової технології утримання суттєво відрізняються від традиційних методів вирощування. При цьому часто фізіологічні можливості організму тварин не в змозі змінюватися так швидко, як того вимагають умови промислового утримання, що призводить до виникнення стресового стану. Тварина у стані стресу помітно втрачає вагу, слабшає, у неї знижується опірність до захворювань, порушується відтворна здатність, відбуваються зміни в метаболізмі, зокрема втрачається енергія, яка б могла використовуватися для росту і розвитку організму. Встановлено, що внаслідок стресу у тварин тваринницькі підприємства несуть значні економічні втрати (Hrabovskyi, 2012; Suprun, 2012; Martyshuk et al., 2019; 2020; Slivinska et al., 2020; Grymak et al., 2020; Leskiv et al., 2021; Nazaruk et al., 2021).

Наявний на ринку України асортимент ветеринарних препаратів та кормових добавок активно поповнюється новими зразками вітчизняного та імпортного виробництва. На сьогодні більшість вітчизняних виробників ветеринарних препаратів вдаються до виробництва генеричних препаратів (препаратів-аналогів) різних фармацевтичних груп. Для підвищення стійкості до стресових ситуацій, профілактики захворювань, підвищення резистентності, збереженості та продуктивності сільськогосподарських тварин спеціалістами ветеринарної медицини широко використовуються ветеринарні препарати та біологічно активні кормові добавки (Zhyla et al., 2015; Chalmeh et al., 2020).
Дотримання системи доклінічних та клінічних випробувань ветеринарних лікарських засобів, яка відповідає міжнародним вимогам, є основною запорукою розробки ефективних, безпечних та конкурентоспроможних препаратів (Saliy et al., 2020). Актуальною $є$ оцінка впливу препарату на метаболічні процеси в організмі тварини за гематологічними, біохімічними та імунологічними показниками, які об'єктивно характеризують його безпечність, клінічний перебіг захворювання та одужання, прояв побічних ефектів та виникнення рецидивів (VICH GL9, 2000; Kotsiumbas et al., 2006; VICH GL43, 2008; Zhyla, 2011; Kotsiumbas et al., 2013; Zhyla et al., 2016).

Препарат L-Цин, розчин для ін'єкцій, є лікарським засобом вітчизняного виробництва (РП: АВ-09278-0119), дія якого зумовлена рецептурною комбінацією діючих речовин, а саме: бутафосфаном, вітамінами групи В (вітаміном $\mathrm{B}_{12}$, вітаміном $\mathrm{B}_{3}$ ) та Lкарнітином, ATC vet класифікаційний код препарату QA12C. Інші мінеральні добавки, QA12CX91 Бутафосфан.

Бутафосфан - це органічна сполука фосфору, відкрита фахівцями компанії “Байєр” в 1926 році, впливає на ряд асиміляційних процесів в організмі тварин, стимулює синтез протеїнів, пришвидшує ріст і розвиток тварин, нормалізує функціонування печінки, підвищує неспецифічну резистентність організму, сприяє утворенню кісткової тканини. При стресових ситуаціях бутафосфан нормалізує рівень гормону стресу гідрокортизону, завдяки чому поліпшує утилізацію глюкози в крові та сприяє збереженню енергетичних ресурсів організму (Martyshuk \& Gutyj, 2019).

Вітамін $\mathrm{B}_{12}$ (ціанокобаламін) відіграє важливу роль в регуляції функцій кровотворних органів, бере участь у синтезі пуринових, піримідинових основ, нуклеїнових кислот, необхідних для процесу еритропоезу, а нормальний білковий, жировий i вуглеводний обміни неможливі без участі вітаміну $\mathrm{B}_{12}$.

Ефективність комбінації бутафосфану та ціанокобаламіну досліджена й описана в науковій літературі 
(Kreipe et al., 2011; Nuber et al., 2015; Chalmeh et al., 2020). На ринку присутні ветеринарні препарати 3 комбінацією бутафосфану та ціанокобаламіну, такі як Катозал ("Bayer HealthCare LLC", США), Ціанофор (TOB “Ветсинтез”, м. Харків), Ветозал (O.L.KAR, м. Шаргород). Відомі також поєднання даної комбінації з карнітином, або з нікотинамідом.

Нікотинамід (вітамін $\mathrm{B}_{3}$, (РP)) стимулює продукування нікотинаденін-динуклеотидфосфату (НАДФ) i нікотинаденіндинуклеотиду (НАД), що регулює перебіг більшості окисно-відновних реакцій, забезпечуючи нормалізацію багатьох видів обміну (включаючи i енергетичний). Цей вітамін присутній у метаболізмі жирів, протеїнів, амінокислот, пуринів, тканинному диханні, глікогенолізі. Нікотинамід має дезінтоксикаційні властивості, швидко розподіляється в тканинах і проходить через плацентарний бар'єр (Lourens \& Benyt, 1991; Nelson \& Cox, 2017).

L-карнітин (вітамін $\mathrm{B}_{11}$ ) є продуктом біосинтезу лізину та метіоніну, в організмі виконує ряд важливих функцій, серед яких: детоксикація, стимуляція метаболічних процесів, зміцнення судин, стимуляція регенерації тканин. Його застосування сприяє підвищенню витривалості організму, поліпшенню роботи серця, збільшенню м'язової маси за рахунок пришвидшення обмінних процесів у клітинах, сприяє проникненню до клітин вітамінів, мінералів та виведення продуктів розпаду, зменшенню ризику виникнення жирової дистрофії печінки (Lourens \& Benyt, 1991; Nelson \& Cox, 2017; Tarasenko et al., 2007).

Науковий інтерес викликає дослідження ефективності нової комбінації зі збалансованого комплексу активних діючих речовин, таких як бутафосфан, вітамін $\mathrm{B}_{12}$, нікотинамід (вітамін $\mathrm{B}_{3}$ ) та L-карнітин (вітамін $\left.\mathrm{B}_{11}\right)$. Метою нашої роботи було вивчити терапевтичну ефективність у коней препарату L-цин, як тонізуючого засобу з оригінальною комбінацією з чотирьох діючих речовин за дії різних стрес-факторів: при надмірному навантаженні, у складі комплексної терапії захворювань різної етіології.

\section{Матеріал і методи досліджень}

Клінічні випробування препарату проводили у НВЦ “Комарнівський” (с. Переможне Городоцького p-ну Львівської обл.) на робочих конях віком 515 років різної статі. Лабораторні дослідження проводили в лабораторії клініко-біологічних досліджень ДНДКІ ветпрепаратів та кормових добавок.

Для вирішення поставленого завдання було проведено два досліди: перший - дослідження ефективності застосування препарату L-цин на конях у період інтенсивних навантажень; другий - дослідження ефективності застосування препарату L-цин коневі у складі комплексної терапії при лікуванні інтоксикації з ознаками гострої ниркової недостатності.

Дослід 1. При клініко-діагностичному обстеженні поголів'я у господарстві було відібрано 5 робочих коней різної статі та віку. Загальний клінічний стан та вгодованість відібраних тварин були задовільними. Взяття зразків крові від дослідних коней проводили до початку застосування препарату L-цин та на 10 добу після останнього введення препарату. Препарат вводили внутрішньом'язово, в дозі 20 мл 1 раз на добу впродовж 5 діб поспіль. За клінічним станом дослідних тварин спостерігали упродовж 21 доби від початку застосування препарату.

Дослід 2. Лікування гострої інтоксикації у коня. Після проведеного клінічного огляду хворого коня було відібрано кров з яремної вени для лабораторного дослідження. На основі клінічних даних та результатів дослідження крові лікарем було поставлено діагноз - інтоксикація з ознаками гострої ниркової недостатності і призначено лікування, яке включало препарати: знеболюючої, спазмолітичної, протизапальної та антигістамінної дії, регідратаційну терапію. До складу комплексної терапії з 2 доби лікування також входив досліджуваний нами препарат L-цин у дозі 25 мл за внутрішньовенного введення впродовж 5 діб поспіль.

Морфо-функціональний стан організму тварин до та після застосування препарату встановлювали за клінічним станом, морфологічними та біохімічними показниками крові, які визначали згідно зі загальноприйнятими методиками (Lapovets et al., 2011; Vlizlo et al., 2012; Kotsiumbas et al., 2014). Для оцінки загального стану та характеристики змін основних параметрів організму тварин було підібрано низку лабораторних тестів, що відповідали вимогам до клінічних випробувань препаратів даної фармакотерапевтичної групи (European Treaty Series/123; VICH GL9, 2000; Levchenko et al., 2002; Horbatiuk, 2004; VICH GL43, 2008; Lapovets et al., 2011; Kotsiumbas et al., 2013). Для морфологічних досліджень використовували зразки крові коней, стабілізовані ЕДТА, а для біохімічних досліджень - сироватку крові (СК). Гематологічні дослідження (кількість еритроцитів, лейкоцитів, вміст гемоглобіну, гематокрит, еритроцитарні індекси (MCHC, MCV, MCH) проводили за допомогою автоматичного аналізатора Mythic 18 Vet 3 використанням принципу імпедансометрії. Лейкограму досліджували шляхом мікроскопії мазків крові, зафарбованих барвником Романовського-Гімзи.

Вміст загального білка, глюкози, сечовини, креатиніну, активність аланінамінотрансферази (АлАТ), аспартатамінотрансферази (АсАТ), лужної фосфатази (ЛФ), лактатдегідрогенази (ЛДГ), креатинкінази (КК) у сироватці крові коней визначали за допомогою напівавтоматичного біохімічного аналізатора HumaLyzer 3000 , iз використанням стандартизованих наборів Human Diagnostics Worldwide (Німеччина).

Отримані результати обробляли статистично, оцінюючи вірогідність різниці показників (Р < 0,05,) за критерієм Стьюдента. За статистично-достовірний результат брали різницю між величинами, при якій рівень імовірності різниці (Р) був не більше ніж 0,05 , що $є$ загальноприйнятим підходом у лабораторних дослідженнях.

Наявність та ступінь достовірних різниць досліджуваних показників до та після застосування препарату свідчить про вираженість специфічної фармакологічної дії препарату (CVMP/EWP/81976/2010). 


\section{Результати та їх обговорення}

У першому досліді вивчали ефективність застосування препарату L-цин на конях у період інтенсивних навантажень. Лабораторними дослідженнями до початку застосування препарату встановлено, що значення більшості гематологічних та біохімічних показників крові були в межах фізіологічної норми для тварин даного виду (табл. 1, 2).

Проте кількість лейкоцитів була на рівні максимальної фізіологічної норми, а активність ЛДГ - вища від норми більш ніж у два рази. Така висока активність ензиму, очевидно, $\epsilon$ наслідком хронічних фізичних навантажень, бо ЛДГ є ферментом вуглеводного обміну, причому найбільша його активність спостерігається у скелетних і серцевому м'язах, нирках, печінці та еритроцитах. ЛДГ каталізує одну з найважливіших реакцій гліколізу - взаємоперетворення піровиноградної та молочної кислот і є важливим біохімічним діагностичним тестом для оцінки роботи м'язової тканини в умовах анаеробного гліколізу при фізичних навантаженнях (Tarasenko et al., 2007; Lapovets et al., 2011; Nelson \& Cox, 2017).

На 10 добу після застосування препарату при аналізі гематологічних показників у коней відзначали вірогідне збільшення, в межах норми, вмісту гемоглобіну на $12 \%(\mathrm{P} \leq 0,05)$, тенденцію до збільшення кількості еритроцитів і гематокриту та вірогідне зменшення кількості лейкоцитів й еозинофілів на 19,4 і 41,9 \% відповідно порівняно з показниками до введення препарату (табл. 1).

При аналізі біохімічних показників у цей період встановлено вирогідне підвищення у 4,1 раза $(\mathrm{P} \leq 0,05)$ активності КК (каталізує утворення з АТФ і креатину високоенергетичної сполуки креатинфосфату, яка витрачається організмом при збільшених фізичних навантаженнях), в 1,6 раза $(\mathrm{P} \leq 0,05)$ активності AcАТ (амінотрансфераза, яка виявляє найбільшу ферментативну активність у серцевому м'язі, в значній кількості присутня в м'язах опорно-рухового апарату і гепатоцитах) та зниження в 1,6 раза $(\mathrm{P} \leq 0,05)$ активності ЛДГ. Ферменти КК, АсАТ та ЛДГ є маркерами стану кардіоміоцитів і міокарда в цілому (Tarasenko et al., 2007; Lapovets et al., 2011; Nelson \& Cox, 2017).

Поряд 3 тим у СК виявляли тенденцію до збільшення вмісту креатиніну та загального білірубіну. Показники вмісту глюкози та сечовини змінювалися не суттєво. Варто зауважити, що коливання усіх цих показників не перевищували їхньої фізіологічної норми для коней (табл. 2).

Таблиця 1

Гематологічні показники коней при застосуванні препарату L-цин, $(\mathrm{M} \pm \mathrm{m}, \mathrm{n}=5)$

\begin{tabular}{|c|c|c|c|}
\hline Показники & До введення & 10 доба після введення & Фізіологічні межі \\
\hline Гемоглобін, г/л & $123,3 \pm 2,8$ & $138,3 \pm 3,2^{*}$ & $80-160$ \\
\hline Еритроцити, Т/л & $6,6 \pm 0,4$ & $7,4 \pm 0,2$ & $5,5-10,0$ \\
\hline Гематокрит, \% & $37,3 \pm 2,1$ & $39,8 \pm 1,4$ & $24-52$ \\
\hline МCH, пг & $18,7 \pm 0,2$ & $18,4 \pm 0,3$ & $10-20$ \\
\hline $\mathrm{MCHC}$, г/дл & $33,0 \pm 0,3$ & $35,4 \pm 0,2$ & $20-37$ \\
\hline $\mathrm{MCV}$, мкм $^{3}$ & $56,8 \pm 2,3$ & $53,1 \pm 1,2$ & $35-58$ \\
\hline ШОЕ, мм/за 30 хв & $22,7 \pm 1,8$ & $31,3 \pm 1,5$ & До 107 за 30 хв. \\
\hline мм/3a 45 хв & $36,3 \pm 2,7$ & $41,3 \pm 0,9$ & До 124 за 45 хв. \\
\hline Лейкоцити, Г/л & $12,9 \pm 0,5$ & $10,4 \pm 0,3 *$ & $5,5-12,0$ \\
\hline Базофіли, \% & 0 & 0 & $0-3$ \\
\hline Еозинофіли, \% & $9,3 \pm 0,8$ & $5,4 \pm 0,3^{*}$ & $2-12$ \\
\hline Нейтрофіли паличкояд., \% & $4,7 \pm 0,9$ & $3,3 \pm 0,8$ & $0-6$ \\
\hline Нейтрофіли сегментояд., \% & $42,0 \pm 2,8$ & $46,7 \pm 1,5$ & $35-75$ \\
\hline Лімфоцити, \% & $42,0 \pm 1,5$ & $38,0 \pm 1,2$ & $15-50$ \\
\hline Моноцити, \% & $3,0 \pm 0,8$ & $5,3 \pm 0,9$ & $2-5$ \\
\hline
\end{tabular}

Примітка: тут і надалі:* - $\mathrm{P} \leq 0,05$ порівняно з періодом до застосування препарату.

Таблиця 2

Біохімічні показники сироватки крові коней при застосуванні препарату L-цин (M \pm m, n =5)

\begin{tabular}{lccc}
\hline \multicolumn{1}{c}{ Показники } & До введення & 10 доба після введення & Фізіологічні межі \\
\hline Загальний білок, г/л & $71,1 \pm 1,4$ & $74,7 \pm 1,2$ & $60-78$ \\
Загальний білірубін, мкмоль/л & $8,9 \pm 1,8$ & $17,3 \pm 3,2^{*}$ & $7-25$ \\
КК, Од/л & $97,5 \pm 6,0$ & $404,6 \pm 16,9^{*}$ & $90-560$ \\
АсАТ, Од/л & $208,0 \pm 8,2$ & $328,7 \pm 14,1^{*}$ & $50-350$ \\
АлАТ, Од/л & $14,0 \pm 0,8$ & $13,2 \pm 0,6$ & $3-25$ \\
ЛДГ, Од/л & $1018,0 \pm 182,8$ & $650,0 \pm 103,4^{*}$ & $250-500$ \\
Сечовина, ммоль/л & $5,1 \pm 0,7$ & $7,1 \pm 0,5$ & $4,15-7,47$ \\
Креатинін, мкмоль/л & $98,3 \pm 14,8$ & $117,8 \pm 9,8$ & $106-167$ \\
Глюкоза, ммоль/л & $5,5 \pm 0,6$ & $4,7 \pm 0,3$ & $3,1-6,2$ \\
\hline
\end{tabular}


На 8-10 добу після останнього введення препарату клінічний стан тварин поліпшився, коні стали активнішими, зріс апетит. Впродовж періоду клінічного дослідження у тварин не було зафіксовано випадків захворювання. Під час застосування препаратів та після проведеного лікування проявів побічних реакцій чи негативних явищ у коней не спостерігалося.

У другому досліді лікарем ветеринарної медицини господарства при клінічному обстеженні хворої тварини встановлено: порушення поведінкової реакції, неспокій, відсутність апетиту, тремор м'язів, черевна стінка напружена, болюча при пальпації, фекалії розрідженої консистенції, сечовиділення зменшене. Про- цес розвивався у гострій формі. Температура тіла тварини коливалася в межах $36,0-36,5{ }^{\circ} \mathrm{C}$, частота дихання становила 18 дих. рухів/хв, пульс - 40 ударів за хвилину.

За клінічним станом тварини проводили постійне спостереження. Поліпшення клінічного стану виявляли на 3 добу лікування. Клінічні симптоми захворювання зникали на 7-8 добу.

Аналізуючи результати морфологічних та біохімічних показників, у хворого коня виявили збільшення кількості лейкоцитів, у лейкограмі - збільшення відсотка паличкоядерних нейтрофільних гранулоцитів та зменшення кількості еритроцитів (табл. 3).

Таблиця 3

Результати морфологічних та біохімічних досліджень хворого коня

\begin{tabular}{lcccc}
\hline \multicolumn{1}{c}{ Показники } & До лікування & $\begin{array}{c}\text { доба від початку } \\
\text { лікування }\end{array}$ & $\begin{array}{c}10 \text { доба від початку } \\
\text { лікування }\end{array}$ & $\begin{array}{c}\text { Фізіологічні } \\
\text { межі }\end{array}$ \\
\hline Еритроцити, Т/л & 5,1 & 6,3 & 6,3 & $5,5-10$ \\
Гемоглобін, г/л & 100 & 100 & 118 & $80-160$ \\
Лейкоцити, Г/л & 18,4 & 8,6 & 8,5 & $2,5-12,0$ \\
Еозинофіли, \% & 7 & 2 & 4 & $0-12$ \\
Базофіли, \% & 0 & 0 & 0 & $0-6$ \\
Нейтрофіли паличкоядерні, \% & 12 & 7 & 4 & $35-75$ \\
Нейтрофіли сегментоядерні, \% & 68 & 69 & 48 & $15-50$ \\
Лімфоцити, \% & 5 & 15 & 38 & $2-5$ \\
Моноцити, \% & 8 & 7 & 6 & $60-78$ \\
Загальний білок, г/л & 116,3 & 74,4 & 70,2 & $29-59$ \\
Альбумін, г/л & 54,3 & 35,1 & $7-25$ \\
Загальний білірубін, мкмоль/л & 15,0 & 25,7 & 18,9 & $100-300$ \\
ЛФ, Од/л & 626,8 & 428,3 & 317,9 & $50-350$ \\
АсАТ, Од/л & 622,1 & 635,7 & 327,1 & $3-25$ \\
АлАТ, Од/л & 62,29 & 48,4 & 24,3 & $250-500$ \\
ЛДГ, Од/л & 495,3 & 381,7 & 348,9 & $4,1-7,5$ \\
Сечовина, ммоль/л & 24,8 & 6,0 & 6,3 & $106-167$ \\
Креатинін, мкмоль/л & 515,7 & 93,8 & 105,4 & $1,3-2,8$ \\
Заг. холестерол, & 30,6 & 5,9 & 3,2 & $3,1-6,2$ \\
Глюкоза, ммоль/л & 4,2 & 4,9 & 5,5 & $2,2-3,1$ \\
Кальцій, ммоль/л & 1,3 & 2,5 & 2,4 & $1,1-1,9$ \\
Фосфор, ммоль/л & 5,2 & 1,5 & 1,3 \\
\hline
\end{tabular}

При аналізі біохімічних показників у СК встановлено збільшення вмісту загального білка, сечовини, креатиніну, загального холестерину та Фосфору на фоні зменшення вмісту Кальцію, також значне підвищення активності амінотрансаміназ та ЛФ. Нормалізація показників крові хворої тварини відбулася на 10 добу від початку лікування (табл. 3).

Таким чином, за результатами проведеного лікування можна зробити висновок, що у складі комплексної терапії при лікуванні інтоксикації у коня застосування препарату L-цин сприяло поліпшенню клінічного стану, нормалізації морфофункціональних показників організму.

\section{Висновки}

1. При надмірному навантаженні у робочих коней препарат L-цин, розчин для ін'єкцій, виявляв терапевтичну ефективність: активував процеси кровотворення, поліпшував показники фізіологічного стану організму та сприяв підвищенню загального тонусу організму. Препарат не проявив неочікуваної негативної місцевої та загальної дії.

2. Застосування препарату L-цин коневі у складі комплексної терапії при лікуванні інтоксикації сприяло швидкому поліпшенню клінічного стану та нормалізації морфофункціональних показників організму. Препарат виявляв гепато- та нефропротекторні властивості, знижував прояви інтоксикації, сприяв відновленню нормального фізіологічного стану тварини.

3. Впровадження у клінічну ветеринарну практику лікарського засобу L-цин зумовить розширення переліку препаратів даної групи, дасть можливість практичним лікарям ветеринарної медицини застосовувати його як за монотерапії, так і для комплексного лікування захворювань різної етіології у коней.

Відомості про конфлікт інтересів. Автори стверджують про відсутність конфлікту інтересів щодо їх вкладу та результатів досліджень. 


\section{References}

Chalmeh, A., Pourjafar, M., \& Badiei, K. (2020). Intravenous Administration of Butaphosphan and Cyanocobalamin Combination to Late-Pregnant Dairy Cows Reduces Their Insulin Resistance After Calving. Biol Trace Elem Res. doi: 10.1007/s12011-020-02330-5.

Directive 81/852/EEC and EU guideline "Good clinical practice clinical trials on veterinary medicinal products in the European Union".

European Treaty Series/123. European Convention for the Protection of Vertebrate Animals used for Experimental and Other Scientific Purposes. Strasbourg, 18.III.1986. URL: https://rm.coe.int/168007a67b.

Grymak, Y., Skoromna, O., Stadnytska, O., Sobolev, O., Gutyj, B., Shalovylo, S., Hachak, Y., Grabovska, O., Bushueva, I., Denys, G., Hudyma, V., Pakholkiv, N., Jarochovich, I., Nahirniak, T., Pavliv, O., Farionik, T., \& Bratyuk, V. (2020). Influence of "Thireomagnile" and "Thyrioton" preparations on the antioxidant status of pregnant cows. Ukrainian Journal of Ecology, 10(1), 122-126. doi: 10.15421/2020 19.

Horbatiuk B. I. (2004). Metodychni rekomendatsii z diahnostyky ta doslidzhennia zahalnoho stanu orhanizmu tvaryn. Lviv (in Ukrainian).

Hrabovskyi, S. S. (2012). Stresy silskohospodarskykh tvaryn ta yoho naslidky. Naukovyi visnyk Lvivskoho natsionalnoho universytetu veterynarnoi medytsyny ta biotekhnolohii imeni S. Z. Hzhytskoho, 14(3(53), 4758 (in Ukrainian).

Kotsiumbas, I. Ya, Bisiuk, I. Yu., Horzheiev, V. M., \& Malyk O. H. (2013). Klinichni doslidzhennia veterynarnykh preparativ ta kormovykh dobavok. L.:TOV Vydavnychyi dim "SAM" (in Ukrainian).

Kotsiumbas, I. Ya., Malyk, O. H., \& Patereha, I. P. (2006). Doklinichni doslidzhennia veterynarnykh likarskykh zasobiv. Lviv: Triada plius (in Ukrainian).

Kotsiumbas, I. Ya., Zhyla, M. I., \& Pyatnychko, O. M. (2014). Imunotoksykolohichnyi kontrol veterynarnykh preparativ ta kormovykh dobavok: Metodychni rekomendatsii. Lviv (in Ukrainian).

Kreipe, L., Deniz, A., Bruckmair, R. V., \& van Dorland, H. A. (2011). First report about the mode of action of combined butafosfan and cyanocobalamin on hepatic metabolism in nonketotic early lactating cows. Journal of dairly science, 94(10), 4904-4914 doi: 10.3168/jds.2010-4080.

Lapovets, L. Ye., Lutsyk, B. D., \& Lebed, H. B. (2011). Klinichna laboratorna diahnostyka. Praktykum. Lviv (in Ukrainian).

Leskiv, Kh Ya., Gufriy, D. F., Gutyj, B. V., Khalak, V. I., Hariv, I. I., Martyshuk, T. V., \& Guta, Z. A. (2021). The effect of methiphene, methionine, and phenarone on the humoral part of the immune System of piglets in experimental chronic nitrate-nitrite toxicosis Colloquium-journal, 7(94), 12-15. doi: 10.24412/25206990-2021-794-12-15.

Levchenko, V. I., Vlizlo, V. V., \& Kondrakhin, I. P. (2002). Veterynarna klinichna biokhimiya. Bila Tserkva (in Ukrainian).
Levchenko, V. Y., Kondrakhyn, Y. P., Sudakov, N. A., \& Chumachenko, V. Iu. (1999). Vnutrennye bolezny zhyvotnykh. Belaya Tserkov (in Russian).

Lourens, D. R., \& Benyt. P. N. (1991). Klynycheskaia farmakolohyia. M.: Medytsyna (in Russian).

Martyshchuk, T. V., \& Gutyi, B. V. (2019). Influence of feed additive "Butaselmevit Plus" on the indicators of rats blood under the conditions of their poisoning with Tetrachloromethane. Theoretical and Applied Veterinary Medicine, 7(2), 79-83. doi: 10.32819/2019.71014.

Martyshuk, T. V., \& Gutyj, B. V. (2019). Influence of feed additive "Butaselmevit-Plus" on antioxidant status of rats in conditions of oxidative stress. Scientific Messenger of Lviv National University of Veterinary Medicine and Biotechnologies. Series: Agricultural sciences, 21(90), 76-81. doi: 10.32718/nvlveta9013.

Martyshuk, T. V., Gutyj, B. V., \& Vishchur, O. I. (2019). Morphological and biochemical indices of piglets' blood by the action of feed additive "Butaselmevitplus". The Animal biology, 21(4), 65-70. doi: 10.15407/animbiol21.04.065.

Martyshuk, T. V., Gutyj, B. V., Vishchur, O. I., \& Todoriuk, V. B. (2019). Biochemical indices of piglets blood under the action of feed additive "Butaselmevitplus". Ukrainian Journal of Veterinary and Agricultural Sciences, 2(2), 27-30. doi: 10.32718/ujvas2-2.06.

Martyshuk, T. V., Gutyj, B. V., Zhelavskyi, M. M., Midyk, S. V., Fedorchenko, A. M., Todoriuk, V. B., Nahirniak, T. B., Kisera, Ya. V., Sus, H. V., Chemerys, V. A., Levkivska, N. D., \& Iglitskej, I. I. (2020). Effect of Butaselmevit-Plus on the immune system of piglets during and after weaning. Ukrainian Journal of Ecology, 10(2), 347-352. doi: 10.15421/2020 106.

Nazaruk, N. V., Gutyj, B. V., Gufrij, D. F., Leskiv, Kh. Ya., Ivashkiv, R.M., \& Martyshuk, T. V. (2021). The effect of methyphen and vitamix se on the level of products of bull lipid peroxide oxidation under nitratecadmium load. Colloquium-journal, 7(94), 16-18. doi: 10.24412/2520-6990-2021-794-16-18.

Nelson, D. L., \& Cox, M. M. (2017). Lehninger principles of biochemistry. New York: W. H. Freeman.

Nuber, U., van Dorland, H. A., \& Bruckmaier, R. M. (2015). Effects of butafosfan with or without cyanocobalamin on the metabolism of early lactating cows with subclinical ketosis. J. Anim. Physiol. Anim. Nutr. (Berl.), 100(1), 146-155. doi: 10.1111/jpn.12332.

Saliy, O., Baula, N., \& Sopizhenko, O. (2020). The analysis of the regulatory and legal support for clinical trials of medicines and veterinary preparations in Ukraine and the EU. Management, economy and guality assurance in pharmacy, 4(6), 36-44. doi: 10.24959/uekj.20.34.

Slivinska, L. G., Shcherbatyy, A. R., Lukashchuk, B. O., \& Gutyj, B. V. (2020). The state of antioxidant protection system in cows under the influence of heavy metals. Regulatory Mechanisms in Biosystems, 11(2), 237-242. doi: 10.15421/022035.

Suprun, I. O. (2012). Henezys stresu silskohospodarskykh tvaryn. Biologia tvaryn, 14(1-2), 55-63 (in Ukrainian). 
Tarasenko, L. M., Hryhorenko, V. K., \& Neporada, K. S. (2007). Funktsionalna biokhimiia. Vinnytsia (in Ukrainian).

VICH (2000). VICH GL9: Good clinical practices. URL: https://vichsec.org/en.

VICH (2008). VICH GL43. Target Animal Safety for Veterinary Pharmaceutical Products. URL: https://vichsec.org/en.

Vlizlo, V. V., Fedoruk, R. S., \& Ratych, I. B. (2012). Laboratorni metody doslidzhennia $\mathrm{V}$ biolohii, tvarynnytstvi ta veterynarnii medytsyni: dovidnyk. Lviv: Spolom (in Ukrainian).

Zhyla, M. I. (2011). Laboratorni doslidzhennia pry klinichnomu vyprobuvanni veterynarnykh likarskykh zasobiv. Naukovyi visnyk Lvivskoho natsionalnoho universytetu veterynarnoi medytsyny ta biotekhnolohii imeni S. Z. Hzhytskoho 13, 4(50), 128-134 (in Ukrainian).

Zhyla, M. I., Piatnychko, O. M., \& Shkodiak, N. V. (2015). Terapevtychna efektyvnist veterynarnoho likarskoho zasobu Vetozal $10 \%$ pry likuvanni porosyat $\mathrm{z}$ oznakamy anemii. Naukovo-tekhnichnyi biuleten DNDKI vetpreparativ ta kormovykh dobavok i Instytutu biolohii tvaryn, 16(2), 134-139 (in Ukrainian).

Zhyla, M. I., Piatnychko, O. M., \& Shkodiak, N. V. (2016). Kontrol yakosti henerychnykh veterynarnykh likarskykh zasobiv. Naukovyi visnyk Lvivskoho natsionalnoho universytetu veterynarnoi medytsyny ta biotekhnolohii imeni S.Z. Hzhytskoho, 18, 1(65), 3541 (in Ukrainian). 